\title{
FORMICA WHEELERI: DARWIN'S PREDATORY SLAVE-MAKING ANT?
}

\author{
By Howard TOPOFF* AND Ellen ZimMerLi* ${ }^{*}$
}

\begin{abstract}
INTRODUCTION
Hypotheses concerning the evolution of slavery in ants emphasize the role of excess predation (Darwin, 1859), territorial encounters (Alloway, 1980; Wilson, 1975), or brood transport among polydomous colonies (Buschinger, 1986). Although these views are not mutually exclusive, many investigators have noted the general absence of group predation in dulotic ants (Hölldobler and Wilson, 1990). This has been thought to be true for facultative slave making ants belonging to the genus Formica, although most research has been conducted only on the European species $F$. sanguinea (Dobrzanski, 1965), and the related North American species, F. subintegra (Talbot and Kennedy, 1940). Relatively little is known about the numerous other species belonging to the sanguinea group. For example, although colonies of Formica wheeleri are common in western United States, we have but one account of their raiding and nesting activities (Wilson, 1955). In the mountains of southeastern Arizona, colonies of $F$. wheeleri are sympatric with Polyergus breviceps, an obligatory slave-making ant with which $F$. wheeleri competes for the same slave species. In this paper, we present the results of a field study revealing that $F$. wheeleri may be the only facultative slave-maker to exhibit the general predatory behavior predicted by Darwin's hypothesis for the evolution of slave-making ants.
\end{abstract}

\section{Materials AND Methods}

Seven colonies of Formica wheeleri were monitored from June 16 to July 16, 1991, during the time period 0730-1700 h (MST). All colonies were located in the Chiricahua Mountains, Cochise County, Arizona. The field site is located $14 \mathrm{~km}$ west of Portal,

\footnotetext{
* Department of Psychology, Hunter College of CUNY, 695 Park Avenue, New York, N.Y. 10021, and Department of Entomology, The American Museum of Natural History, New York, N.Y. 10024

Manuscript received 1 November 1991
} 
Arizona. At an elevation of $2750 \mathrm{~m}$, the habitat is dominated by Ponderosa pine and Douglas fir. Although three species of Formica are abundant in this habitat $(F$. occulta, F. marcida, and $F$. neogagates), only $F$. occulta is parasitized in this study site.

\section{RESULTS}

Raiding Activities: The raiding characteristics of five colonies of Formica wheeleri are summarized in Table 1. Prior to the onset of the summer monsoon rains (June 23-July 6), the median time for group raiding was $1405 \mathrm{~h}$. During the rainy season, the median time for group raiding was $4.5 \mathrm{~h}$ earlier. It is likely that the earlier onset of raids after July 6 was due to the corresponding drop in daytime temperature when the rainy season began.

The data presented in Table 1 are only for raids in which at least 20 workers simultaneously left the nest area and proceeded in an organized group toward a target nest. But before and after such raids, every gradation of foraging behavior, from individual exploration to group raiding, was observed. Indeed, for most of the day, the distinction between raiding and individual foraging was entirely moot. When individual foragers left the nest, they scavenged for dead arthropods, as do their $F$. occulta slaves. Slave individuals did not participate in group raids on other colonies of F. occulta.

Predatory Behavior: During most group raids by Formica wheeleri, host workers fled from their nest with brood, fighting between parasite and host was short-lived, and few workers of

Table 1. Summary of Formica wheeleri raiding activities

\begin{tabular}{lccc}
\hline & Range & Median & Sample size \\
\hline No. of F. wheeleri on raid & $21-660$ & 114 & 42 \\
Time of raid onset (MST) & & & \\
$\quad$ June 16-July 06 & $1215-1612$ & 1405 & 18 \\
July 07-July 16 & $0804-1440$ & 0936 & 29 \\
Distance to target nest (m) & $2-31$ & 13 & 42 \\
No. of brood taken (larvae + pupae) & $2-182$ & 25 & 16 \\
\hline
\end{tabular}


either species were killed. Nevertheless, we observed numerous instances when $F$. wheeleri killed the resident $F$. occulta workers and took the dead ants back to their nest. We also observed predation on other species of ants. Our observations of group predation are summarized as follows:

June 26: During a foray conducted by only 13 raiders from colony 4 , one worker of $F$. occulta was killed by three $F$. wheeleri, and dragged back to the nest.

June 27: During a raid by colony 3, two workers of Camponotus and one of Formica marcida were present near the nest of the target $F$. occulta colony. All three ants were promptly killed and taken back to the $F$. wheeleri nest.

June 28: Workers from colony 3 killed eight $F$. occulta workers at the target nest. Again, all were hauled back to the parasite's nest.

June 28: Raiders of $F$. wheeleri moved out in several bursts. At the target nest, the arriving ants extensively excavated the $F$. occulta nest entrance. As the resident workers came to the surface, they engaged in prolonged fights with the intruders. Fifty-five $F$. occulta workers were killed and immediately carried back to the $F$. wheeleri nest.

June 29: Approximately 1 hour prior to a raid by colony 4 , a target nest of $F$. occulta was attacked by a colony of Polyergus breviceps, and approximately $45 F$. occulta workers had been killed (but not removed) by the Polyergus. When the Formica wheeleri raiders arrived at the site, they promptly retrieved every dead worker.

July 12: A raiding party from colony 2 encountered a column of foragers belonging to the species Liometopum apiculatum. Fighting erupted immediately. Although this interaction aborted the slave raid, 28 Liometopum foragers were killed and taken back to the $F$. wheeleri nest. 
July 12: A colony of Formica wheeleri raided a colony of Polyergus. Fighting was intense and workers of both species were killed. Although the Polyergus did not retrieve any dead Formica, the $F$. wheeleri raiders picked up at least 12 dead Polyergus workers, and transported them back to their own nest.

Finally, throughout the month-long observation period, raiders of Formica wheeleri were observed attacking leaf hoppers, small caterpillars, and spiders that inadvertently wandered into the path of a slave-raid swarm. In all such instances, the arthropods were killed and carried back to the $F$. wheeleri nest.

Brood retrieval: Our observations on predatory behavior suggested that Formica wheeleri might be less specialized than Polyergus with respect to species diversity of retrieved brood. To document this, 50 pupae of Camponotus ocreatus (a non-sympatric species) were placed $0.5 \mathrm{~m}$ in front of a $F$. wheeleri raid swarm. The raid halted and all pupae were removed in less than 5 min. When a similar batch of $C$. ocreatus pupae were placed in front of a Polyergus breviceps swarm, the raiders ran over the pupae without hesitating and none of the brood was captured. This procedure was repeated on three consecutive days, each with a different colony of Formica wheeleri and Polyergus. In all cases, every pupa was removed by $F$. wheeleri and none were removed by Polyergus.

A similar, and somewhat more natural, test was conducted on June 30 . At $1330 \mathrm{~h}$, a colony of Polyergus initiated a raid toward a colony of $F$. occulta located $45 \mathrm{~m}$ to the south. En route to the target, the Polyergus raiders encountered a nest of Formica neogagates. Resident workers emerged from the nest, and intense fighting broke out as workers of both species grabbed legs and antennae. After approximately $5 \mathrm{~min}$, panic alarm spread through the $F$. neogagates nest. The queen emerged, followed by hundreds of workers carrying brood. When most of the adult Formica workers had scurried away, the area immediately around the nest entrance was littered with more than one hundred undefended pupae. When fighting ceased, the Polyergus workers regrouped, and proceeded another $10 \mathrm{~m}$ to the target nest of $F$. occulta. Significantly, not one of the $F$. neogagates pupae was retrieved. Eighty- 
five of these pupae were aspirated and placed in front of a raid swarm of Formica wheeleri. All the pupae were retrieved in less than 5 min.

Emigration: Two emigrations were observed during the field season. The first colony moved $2 \mathrm{~m}$ to the east during the period June 23-June 27 , and the second colony emigrated $4 \mathrm{~m}$ to the east from July 2 to July 6 . Throughout the emigrations, both colonies maintained their normal activity schedules. Thus, worker transport commenced at approximately $1300 \mathrm{~h}$, and ceased shortly after $1630 \mathrm{~h}$. In the first colony, workers of Formica wheeleri transported all brood, callows (including callow alates of $F$. wheeleri), and adults of both species. Workers of Formica occulta were never observed carrying other individuals. Their activities were confined to nest maintenance at the new site. In colony 2 , we did observe 1 individual of $F$. occulta carrying an $F$. wheeleri adult. But again, all other brood and adult workers of both species were transferred to the new site by workers of $F$. wheeleri.

\section{DISCUSSION}

Facultative slave-making ants, like those in the sanguinea complex, represent an intermediate parasitic group, between freeliving species on the one hand, and obligatory dulotic species on the other. In recent laboratory tests by Mori and Le Moli (1988), slaves were removed from colonies of Formica sanguinea and Polyergus rufescens. Not surprisingly, the behavioral repertory of $F$. sanguinea expanded dramatically within 30 days of slave removal, with workers becoming self sufficient at feeding and brood care. Workers of Polyergus, by contrast, were unable to care for their brood, and experienced high mortality. The behavior of both species during emigrations and foraging (summarized in Table 2) also shows that Formica wheeleri is less specialized than Polyergus.

Most studies on the raiding behavior of species in the $F$. sanguinea complex confirm that slave raiders usually rout their opponents, who typically flee in a state of panic alarm, and that aggressive encounters, when they occur, are brief and do not result in the death of adult individuals from either species (Talbot and Kennedy, 1940). Wheeler (1910) noted, however, that when large 
Table 2. Comparison of behavioral characteristics between Formica wheeleri and Polyergus breviceps.

\begin{tabular}{lll}
\hline & \multicolumn{1}{c}{$F$. wheeleri } & \multicolumn{1}{c}{ P. breviceps } \\
\hline Emigrations & $\begin{array}{l}\text { F. wheeleri adults carry } \\
\text { both brood and adults of } \\
\text { both species to new nest }\end{array}$ & $\begin{array}{l}\text { Only slaves transport adults } \\
\text { and brood of both species to } \\
\text { new nest }\end{array}$ \\
Foraging & $\begin{array}{l}\text { Workers forage individually } \\
\text { and on group raids }\end{array}$ & No individual foraging \\
Brood retrieval & $\begin{array}{l}\text { Workers retrieve brood even } \\
\text { from different ant genera }\end{array}$ & $\begin{array}{l}\text { Only brood from slave or closely } \\
\text { related species retrieved }\end{array}$ \\
Adult ant capture & $\begin{array}{l}\text { Raiders kill and retrieve } \\
\text { adults even from different } \\
\text { ant genera }\end{array}$ & $\begin{array}{l}\text { Raiders rarely kill, and never } \\
\text { retrieve other adults }\end{array}$ \\
\hline
\end{tabular}

colonies of slave species offer resistance during raids, prolonged fighting is possible, and many workers of both species can be killed. Despite numerous instances of such fighting, Wheeler did not observe slave-raiders retrieving dead ants of either species. During the period 1955-1960, Marikovsky (1963) transferred more than 400 colonies of Formica rufa into habitats occupied by $F$. sanguinea. The aggressive $F$. sanguinea virtually destroyed all the introduced $F$. rufa colonies. Marikovsky also reported that Formica sanguinea raided five other species of Formica, as well as Camponotus herculeanus, and Lasius flavus. Although adult workers were routinely killed during these forays, only larvae and pupae were transported back to the Formica sanguinea nest.

More recently, Talbot (1985) studied raids by Formica gynocrates (another facultative parasite belonging to the Raptiformica group), which pillages colonies of Formica vinculans. When attacked, resident workers pick up brood and evacuate their nest, and seek protection at the top of plant stems. Nevertheless, $F$. vinculans workers from large colonies can stage a counterattack, and may be killed in the melee. In one such vigorous raid observed by Talbot, 230 pupae and 89 larvae were captured. Near the end of the raid, when pupa transport dwindled, a few Formica gynocrates workers picked up dead Formica vinculans individuals and carried them home. 
Given the scant evidence for predation by facultative formicine slave-making ants, it is not surprising that researchers have consistently rejected Darwin's claim that dulosis evolved from predatory raiding. It is true that many $F$. wheeleri raids are similar to those reported for other sanguinea group species, in that brood is retrieved after driving resident adults from their nest, and that killing of adults typically only occurs when resident workers actively defend their nest. Nevertheless, it is clear from our observations that Formica wheeleri is the most predatory sanguinea species known to date: (1) it takes adult ants as well as brood, and often just adults of other genera; and (2) this behavior is common.

The discovery of significant predation by Formica wheeleri clearly does not call for a major shift in our ideas about the origin of dulotic behavior. First, it could still be argued that predatory behavior of $F$. wheeleri evolved from intraspecific, territorial raids. Although we observed no such interaction during this field season, we do have one past record of such a territorial encounter. Second, although an evolutionary hypothesis of dulosis based on predation can account for brood capture and the rearing of excess pupae, the important issue of non-independent colony foundation must also be addressed.

We have recently shown (Topoff et al., 1990) that newly mated queens of Formica wheeleri usurp colonies of $F$. occulta by driving out the resident queen and workers, gathering the pupal brood into a pile, and rearing the pupae through eclosion. We have also argued that the ability to usurp the pupal brood of incipient nests belonging to closely related species would be of tremendous selective advantage to a colony-founding queen (Topoff, 1990a, b). Through olfactory conditioning, rearing of raided brood in the nest of the queen's origin could specify the host species colony to be invaded, and could even provide the queen with some degree of host-species olfactory resemblance, similar to that hypothesized for Polyergus (Goodloe and Sanwald, 1985). Such host colony invasions would only be successful, however, if the invading queen usurped pupae from colonies of closely related species, thus ensuring similar ecological requirements. The role of predation in such an evolutionary process would be to facilitate the subsequent capture of additional pupae, with some being used as food, and others reared to become slaves. Although we observed raiders of 
F. wheeleri capturing adult workers of Liometopum, Camponotus, and Formica marcida during slave raids, no nest of these species was invaded. To date, such raids on nests have only been directed toward other colonies of $F$. wheeleri, $F$. occulta, and Polyergus breviceps. If the species to be raided by $F$. wheeleri is influenced by olfactory experience from their own slaves, raids on these three species may be biased, because all contain workers of $F$. occulta. Since we have found no nests of $F$. wheeleri without slaves, we plan to create such homospecific colonies by providing a newlymated queen with several hundred pupae. Our goal is to determine whether such homospecific colonies of $F$. wheeleri will exhibit even greater predation, by expanding the range of species whose nests are raided.

\section{SUMMARY}

In southeastern Arizona, at an elevation of $2750 \mathrm{~m}$, the facultative slave-making ant Formica wheeleri is sympatric with Polyergus breviceps. Although three additional species of Formica are common in this habitat, only colonies of $F$. occulta are raided for slaves. Like other species in the Formica sanguinea complex, every gradation of foraging behavior, from individual exploration to group raiding, was common. Unlike other dulotic species of Formica, however, slave raids often resulted in the killing and retrieval of adult ants (in addition to brood) from the invaded colony. We also observed a raid on a colony of Polyergus, an obligatory slave maker in direct competition with $F$. wheeleri, because it uses the same host species. In this raid, Polyergus adults were also killed and taken back to the $F$. wheeleri nest. Workers of Formica marcida, Camponotus, and Liometopum apiculatum who were foraging in the path of slave-raid swarms were similarly killed and retrieved. These field observations depict a slave-making ant far more predatory than other species in the Formica sanguinea complex.

\section{ACKNOWLEDGEMENTS}

The base of operations for this study was the Southwestern Research Station of the American Museum of Natural History. The study was supported by PSC-CUNY Grant 6-62219, and by 
National Geographic Society Grant 4581-91. We thank David Jaspar for his essential assistance in the field, and Stefan Cover for his typically astute comments on the manuscript.

\section{LiTERATURE Cited}

Alloway, T. M.

1980. The origins of slavery in Leptothoracine ants. Amer. Nat. 115: 247-261.

BUSCHINGER, A.

1986. Evolution of social parasitism in ants. Tree 1: 155-160.

DARWIN, C.

1859. On the origin of species. John Murray, London.

DOBRZANSKI, J.

1965. Genesis of social parasitism among ants. Acta. Biol. Exp. 25: 59-71.

Goodloe, L., AND SANwald, R.

1985. Host specificity in colony-founding by Polyergus lucidus queens (Hymenoptera: Formicidae). Psyche 92: 297-302.

Hölldobler, B., AND WILSON, E. O.

1990. The ants. Harvard University Press, Cambridge, Massachusetts.

MARIKOVSKY, P. I.

1963. The ants Formica sanguinea Latr. as pillagers of Formica rufa Lin. nests. Insectes Soc. 10: 119-128.

Mori, A., AND Le Moli, F.

1988. Behavioural plasticity and domestic degeneration in facultative and obligatory slave-making ant species (Hymenoptera: Formicidae). Monitore Zool. 22: 271-285.

TALBOT, $\mathrm{M}$.

1985. The slave-making ant Formica gynocrates (Hymenoptera: Formicidae). Great Lakes Entomol. 18: 103-112.

TAlbot, M., AND Kennedy, C. H.

1940. The slave-making ant, Formica sanguinea subintegra Emery, its raids, nuptial flights and nest structure. Ann. Entomol. Soc. Amer. 33: 560-577.

TopofF, $\mathrm{H}$.

1990a. The evolution of slave-making behavior in the parasitic ant genus Polyergus. Ethol. Ecol. Evol. 2: 284-287.

1990b. Slave-making ants. Amer. Sci. 78: 520-528.

TOPOFF, H., WeICKERT, T., AND ZimMERLi, E.

1990. A comparative study of colony takeover between queens of facultative and obligatory slave-making ants. J. Insect Behav. 3: 813-817.

WHEELER, W. M.

1910. Ants, their structure, development and behavior. Columbia University Press, New York.

WILSON, E. O.

1955. Division of labor in a nest of the slave-making ant Formica wheeleri Creighton. Psyche 62: 130-133.

1975. Leptothorax duloticus and the beginnings of slavery in ants. Evol. 29: 108-119. 

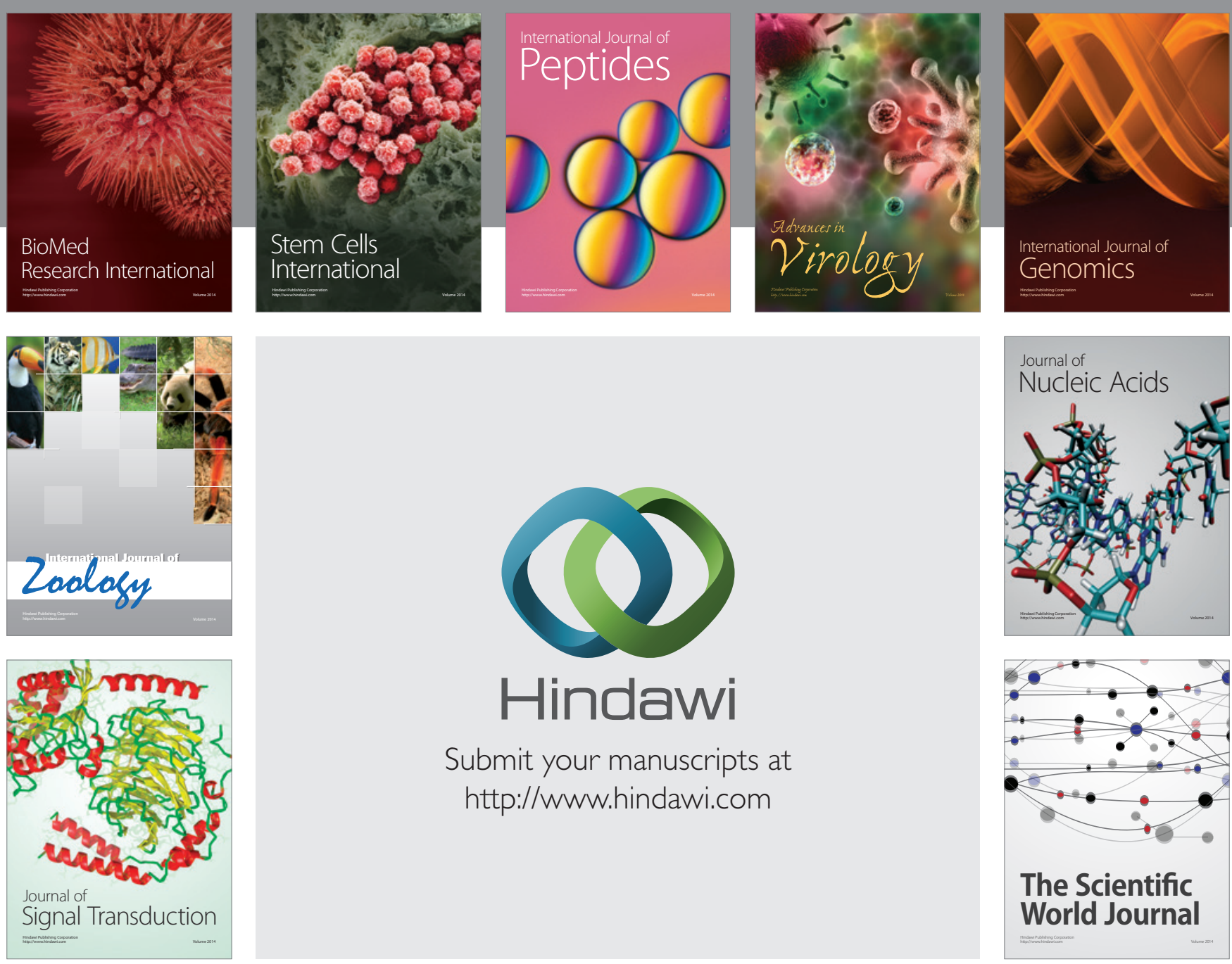

Submit your manuscripts at

http://www.hindawi.com
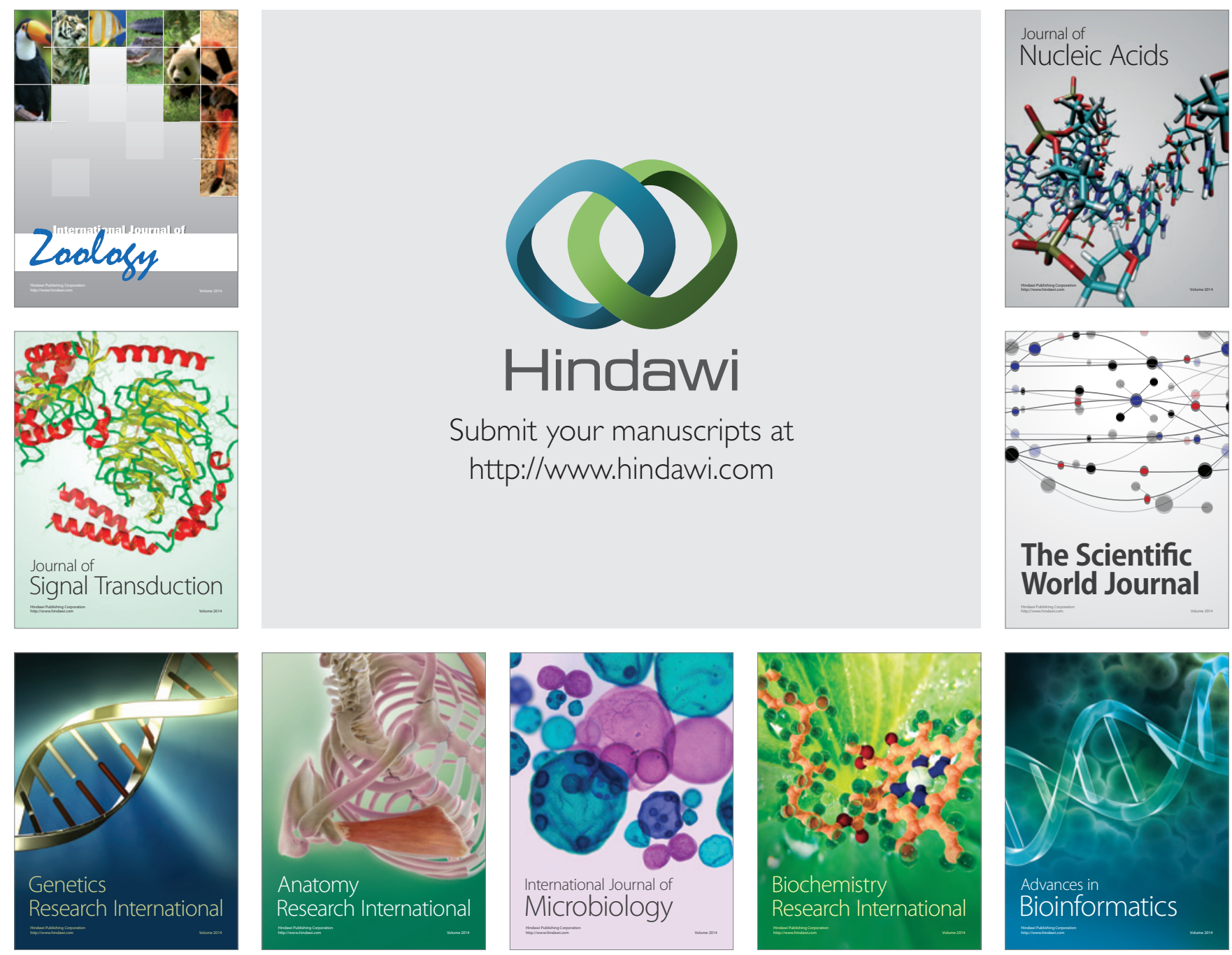

The Scientific World Journal
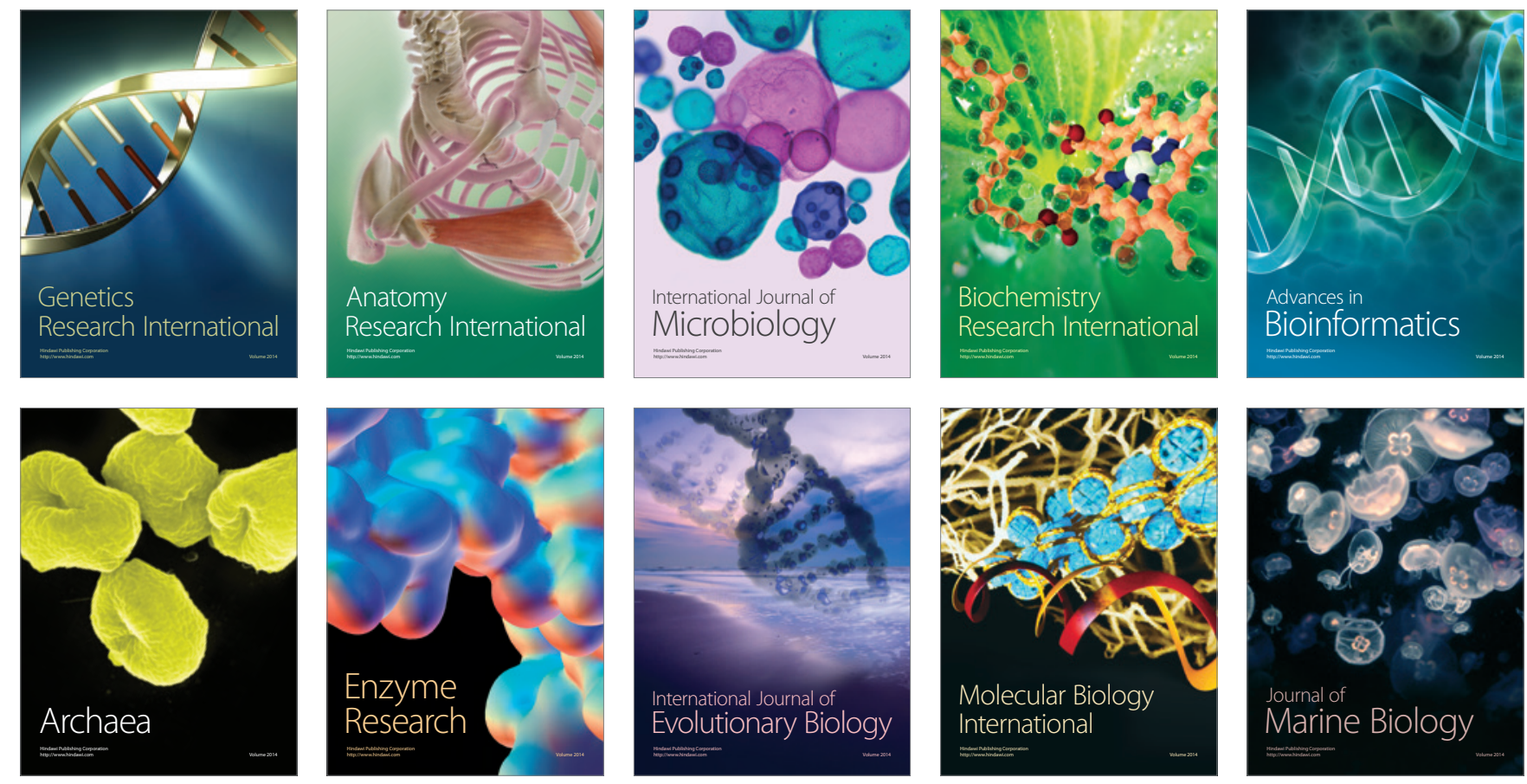